\title{
An immunohistochemical study of pancreatic endocrine cells in SKH-1 hair- less mice
}

\author{
S. K. Ku, H. S. Lee', and J. H. Lee ${ }^{2}$
}

Pharmacology \& Toxicology Laboratory, Central Research Laboratories, Dong-Wha Pharm. Ind. Co, 'Department of Biology, Faculty of Natural Sciences, Kyungsan University and ${ }^{2}$ Department of Histology, College of Veterinary Medicine, Kyungpook National University

Accepted: 02/04/02

Key words: SKH-1 hairless mouse, pancreatic endocrine cell, immunohistochemistry

\section{SUMMARY}

The regional distribution and frequency of the pancreatic endocrine cells in the SKH-1 hairless mouse were studied by an immunohistochemical (peroxidase anti-peroxidase; PAP) method using four types of specific antisera against insulin, glucagon, somatostatin and human pancreatic polypeptide (PP). The pancreas of mice were divided into three portions; pancreatic islets, exocrine and pancreatic ducts. The pancreatic islets were further subdivided into three regions (central, mantle and peripheral region) according to their located types of immunoreactive cells. In the pancreatic islet portions, insulin-immunoreactive cells were located in the central and mantle regions with $84.60 \pm 7.65$ and $33.00 \pm 12.45 / 100$ cells frequencies, respectively, but most of somatostatin-, glucagon- and PPimmunoreactive cells were detected in the mantle and peripheral regions. In the mantle region, somatostatin-, glucagon- and PP-immunoreactive cells were demonstrated with $28.70 \pm 9.91,52.00 \pm 14.05$ and $2.60 \pm 1.51 / 100$ cells frequencies, respectively, and showed $6.20 \pm 2.86,15.30 \pm 5.31$ and $21.50 \pm$ $10.28 / 100$ cells frequencies, respectively in peripheral regions. However, glucagon-immunoreactive cells were also demonstrated in the central regions with $4.00 \pm 2.83 / 100$ cells frequency. In the exocrine portions, insulin-, glucagon-, somatostatin- and PPimmunoreactive cells were demonstrated in the SKH-1 mouse with $0.90 \pm 0.74,0.80 \pm 0.79,4.90 \pm$ 3.54 and $2.70 \pm 1.34 / 100$ cells frequencies, respectively. In the pancreatic duct portions, insulin-, glucagon- and somatostatin-immunoreactive cells were demonstrated in the subepithelial connective tissues and showed islet-like appearances with $30.30 \pm 14.67,2.70 \pm 3.13$ and $5.90 \pm 4.23 / 100$ cells frequencies, respectively. However, no PP-immunoreactive cells were demonstrated in these regions. In conclusion, some peculiar distributional patterns of pancreatic endocrine cells were found in the SKH-1 hairless mouse.

\section{INTRODUCTION}

The SKH-1 hairless mouse is an outbred mouse which is maintained since 1986 in the Charles River Laboratories (Wilmington, U.S.A.).

The hairless and albino background characteristics of the SKH-1 mouse make it useful for a number of tests. It is used, for example in a skin per- 
meability test (Kommuru et al., 1999), as a skin carcinogenesis animal model (Glaso and Wetteland, 1990; Cadi et al., 1991) and in a cutaneous microbiological test including experimental leprosy (Packchaian et al., 1982; Harnby et al., 1990). The appearance, regional distribution and frequency of cells secreting the regulatory hormones, namely insulin and glucagon, in the endocrine pancreas were well recognized by histochemistry (Kobayashi and Alli, 1981), immunofluorescence (Orci, 1982) and immunohistochemistry (Sternberger et al., 1970). Except for the above regulatory hormones, peptide YY-, neuropeptide YY- (AlliRachedi et al., 1984), motilin- (Yamada et al., 1986) and chromogranin family- (Rindi et al., 1986; Ito et al., 1987) immunoreactive cells were also demonstrated in the vertebrate pancreas. The pancreas has been treated as a valuable organ for endocrine studies, and the endocrine pancreas has been extensively studied associated with diabetes (Jansson and Saudler, 1988). In addition, the investigations of gastroenteropancraetic endocrine cells have been considered as an important part of phylogenetic studies (D'Este, et al., 1994). With the increasing demands of diabetic animal models in many fields, the regional distribution and relative frequency of pancreatic endocrine cells, especially insulin- and glucagon-producing cells in laboratory animals, have been a concern in recent years (Warbrittan et al., 1994; Gomez-Dumm et al., 1995; Fu et al., 1996). It had been accepted that insulin-immunoreactive cells were located in the central regions, and other immunoreactive cells, such as glucagon-, somatostatin- and PPimmunoreactive cells were located in the peripheral or mantle regions. However, many researchers held that species-dependent characteristic distributions of cells producing different hormones in the pancreas of each species of animals were due to feeding habits; and this is now generally accepted (Wiezorek et al., 1998). In addition, different regional distributions and relative frequencies of endocrine cells in the pancreatic islets were demonstrated in different portions of the pancreas although they were determined in the same pancreas of the same animal (Yukawa et al., 1999). And a strain-dependent characteristic distribution of these immunoreactive cells was also detected with the increasing production of geneticallymutated laboratory animals and breeding of spe- cific laboratory animals having specific disease or unique nature, especially in rats and mice (Starich et al., 1991; Warbrittan et al., 1994; GomezDumm et al., 1995; Fu et al., 1996; Yukawa et al., 1999). Although many studies have elucidated the regional distribution and relative frequency of different endocrine cells in the pancreas of the various vertebrates, including various species and strains of rodents, there are no reports about immunohistochemical studies on the endocrine cells in the pancreatic islets of the SKH-1 mouse in spite of their biological, physiological and anatomical differences from the other rodents.

The object of this study was to clarify the regional distribution and frequency of the endocrine cells in the pancreas of the SKH-1 mouse by specific immunohistochemistry using four types of specific antisera against insulin, glucagon, somatostatin and PP.

\section{MATERIALS AND METHODS}

Five adult SKH-1 hairless mice (7-weeks old, 26-38 g body weight upon receipt) were acquired from the Charles River Laboratories (Yokohama, Japan) and were used in this study without sexual distinction. After food restriction for about 24 hours, the animals were phlebotomized to bleed under anesthesia with ethylether. Samples from the pancreas were fixed in Bouin's solution. After paraffin embedding, 3-4 $\mu \mathrm{m}$ serial sections were prepared. Representative sections of each tissue were stained with hematoxylin and eosin for light microscopic examination of the normal pancreatic architecture.

Each representative section was deparaffinized, rehydrated and immunostained with the peroxidase anti-peroxidase (PAP) method (Sternberger, 1979). Blocking of nonspecific reactions was performed with normal goat serum prior to incubation with the specific antisera (Table I). After rinsing in phosphate buffered saline (PBS; 0.01M, pH 7.4), the sections were incubated in secondary antiserum. They were then washed in PBS buffer and finally the PAP complex was prepared. The peroxidase reaction was carried out in a solution 3,3'-diaminobenzidine tetrahydrochloride containing $0.01 \% \mathrm{H}_{2} \mathrm{O}_{2}$ in Tris- $\mathrm{HCl}$ buffer $(0.05 \mathrm{M}, \mathrm{pH} 7.6)$. After immunostaining, the sections were lightly counterstained with Mayer's 
Table I

Antisera used in this study

\begin{tabular}{lllc}
\hline Antisera raised* & \multicolumn{1}{c}{ Code } & \multicolumn{1}{c}{ Source } & Dilution \\
\hline Insulin & PUO290395 & BioGenex Lab., San Ramon. & $1: 20$ \\
Glucagon & PUO390598 & BioGenex Lab., San Ramon. & $1: 20$ \\
Somatostatin & PUO421295 & BioGenex Lab., San Ramon. & $1: 20$ \\
PP $^{1}$ & PUO660495 & BioGenex Lab., San Ramon. & $1: 20$ \\
\hline
\end{tabular}

*All antisera were raised in rabbits except for insulin, which was raised in guinea pigs. 'PP: human pancreatic polypeptide

hematoxylin and the immunoreactive cells were observed under a light microscope.

The specificity of each immunohistochemical reaction was determined as recommended by Sternberger (1979), including the replacement of specific antiserum by the same antiserum, which had been preincubated with its corresponding antigen. The frequencies of immunoreactive cells were calculated as mean \pm standard deviation (S.D.) of 10 parts $(\mathrm{n}=10)$ of islets, exocrine and/or duct regions. Among 100 cells, numbers of cells showing immunoreactivities against each antiserum were counted using an automated image analysis process (Soft Image System, Germany) attached to light microscopy. In the pancreatic islets, numbers of immunoreactive cells were counted among 100 cells located in the each portion of islets. In addition, numbers of immunoreactive cells were also counted among 100 cells that were located in exocrine and pancreatic duct regions including epithelial cells of pancreatic duct and acinar cells of exocrine pancreas

\section{RESULTS}

In this study, all four kinds of the immunoreactive endocrine cells were detected with the antisera against insulin, glucagon, somatostatin and PP in the pancreas of SKH-1 hairless mice. The pancreatic islets of this study were distinguished into three distinct layers, central, mantle and peripheral regions with their composition of immunoreactive cells. According to the regions of the pancreas, different regional distribution and frequency of these immunoreactive cells were observed and these differences are shown in Table II. Spherical to spindle, or occasionally, oval to round-shaped immunoreactive cells were located in the pancreas.

\section{In the pancreatic islet portion}

Insulin-immunoreactive cells were located in the central regions with $84.60 \pm 7.65 / 100$ cells frequency. In addition, cells with $33.00 \pm 12.45 / 100$ cells frequency were also demonstrated in the mantle regions, intermingled with other immunoreac-

Table II

Regional distributions and frequencies of the endocrine cells in the pancreas of the SKH-1 hairless mouse

\begin{tabular}{lccccc}
\hline \multirow{2}{*}{$\begin{array}{l}\text { Immunoreactive } \\
\text { cells }\end{array}$} & Central & Mantle & Peripheral & $\begin{array}{c}\text { Exocrine } \\
\text { portion }\end{array}$ & $\begin{array}{c}\text { Pancreatic } \\
\text { duct portion }\end{array}$ \\
\cline { 2 - 6 } & & & - & $0.90 \pm 0.74$ & $30.30 \pm 14.67$ \\
Insulin & $84.60 \pm 7.65$ & $33.00 \pm 12.45$ & $15.30 \pm 5.31$ & $0.80 \pm 0.79$ & $2.70 \pm 3.13$ \\
Glucagon & $4.00 \pm 2.83$ & $52.00 \pm 14.05$ & $6.20 \pm 2.86$ & $4.90 \pm 3.54$ & $5.90 \pm 4.23$ \\
Somatostatin & - & $28.70 \pm 9.91$ & $21.50 \pm 10.28$ & $2.70 \pm 1.34$ & - \\
$\mathrm{PP}^{1}$ & - & $2.60 \pm 1.51$ & 21.50 &
\end{tabular}

Mean \pm S.D. $(n=10) / 100$ cells; ${ }^{\text {PP: }}$ human pancreatic polypeptide; - , not detected. 
tive cells. However, no insulin-immunoreactive cells were found in the peripheral regions where the predominant cell types were PP-immunoreactive (Fig. 1a). Glucagon-immunoreactive cells were located in the mantle and peripheral regions of pancreatic islets with $52.00 \pm 14.05$ and $15.30 \pm$ $5.31 / 100$ cells frequencies, respectively (Fig. $2 \mathrm{a}, \mathrm{b}$ ). In mantle and peripheral regions, cytoplasmic processes of glucagon-immunoreactive cells were intermingled with other immunoreactive cells, especially somatostatin- and PP-immunoreactive cells. In addition, glucagon-immunoreactive cells with $4.00 \pm 2.83$ frequency were demonstrated in the central regions where numerous insulin-immunoreactive cells were found (Fig. 2a, b). Somatostatinimmunoreactive cells were located in the mantle and peripheral regions with $28.70 \pm 9.91$ and $6.20 \pm$ 2.86/100 cells frequencies, respectively. However, no somatostatin-immunoreactive cells were demon-
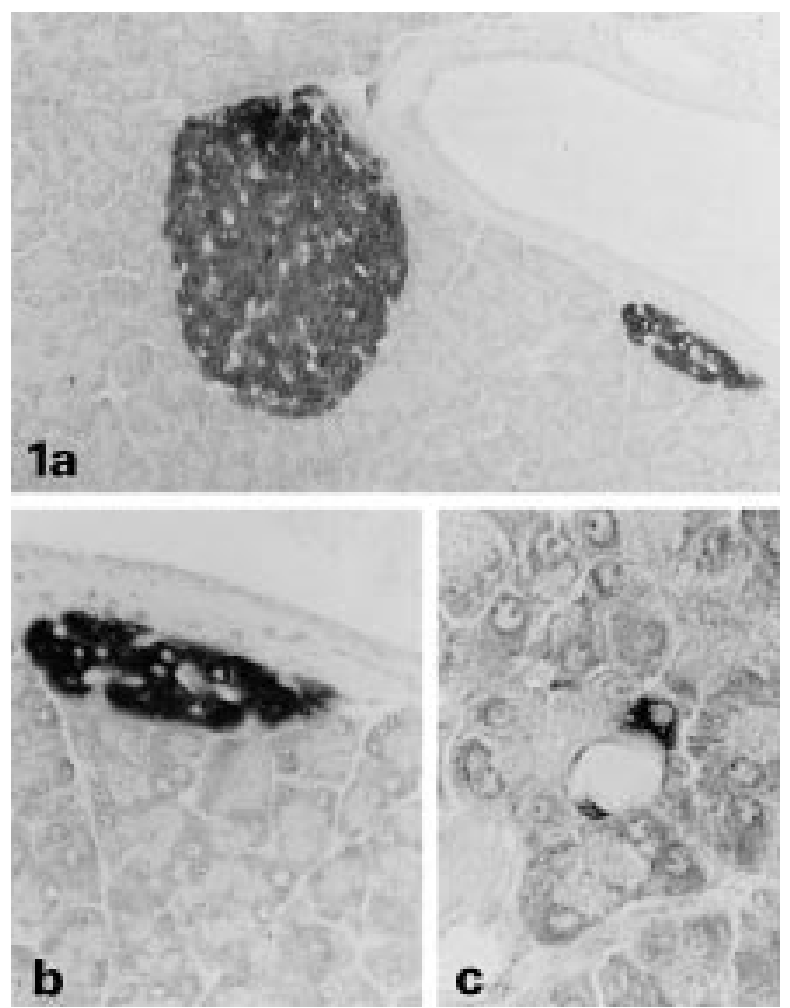

Fig. 1 - Insulin-immunoreactive cells in the pancreas of SKH-1 hairless mice; These cells are situated in the central and mantle regions of pancreatic islets (a) and are also located in the islet-like cell masses situated in the subepithelial connective tissues of the pancreatic duct $(a, b)$ and exocrine portions (c). $\mathbf{a}: \times 120, \mathbf{b}: \times 120, \mathbf{c}: \times 480$, PAP method. strated in the central regions where numerous insulin-immunoreactive cells were found (Fig. 3a, b). PP-immunoreactive cells were located in the mantle and peripheral regions with $2.60 \pm 1.51$ and $21.50 \pm 10.28 / 100$ cells frequencies, respectively (Fig. 4a-c).
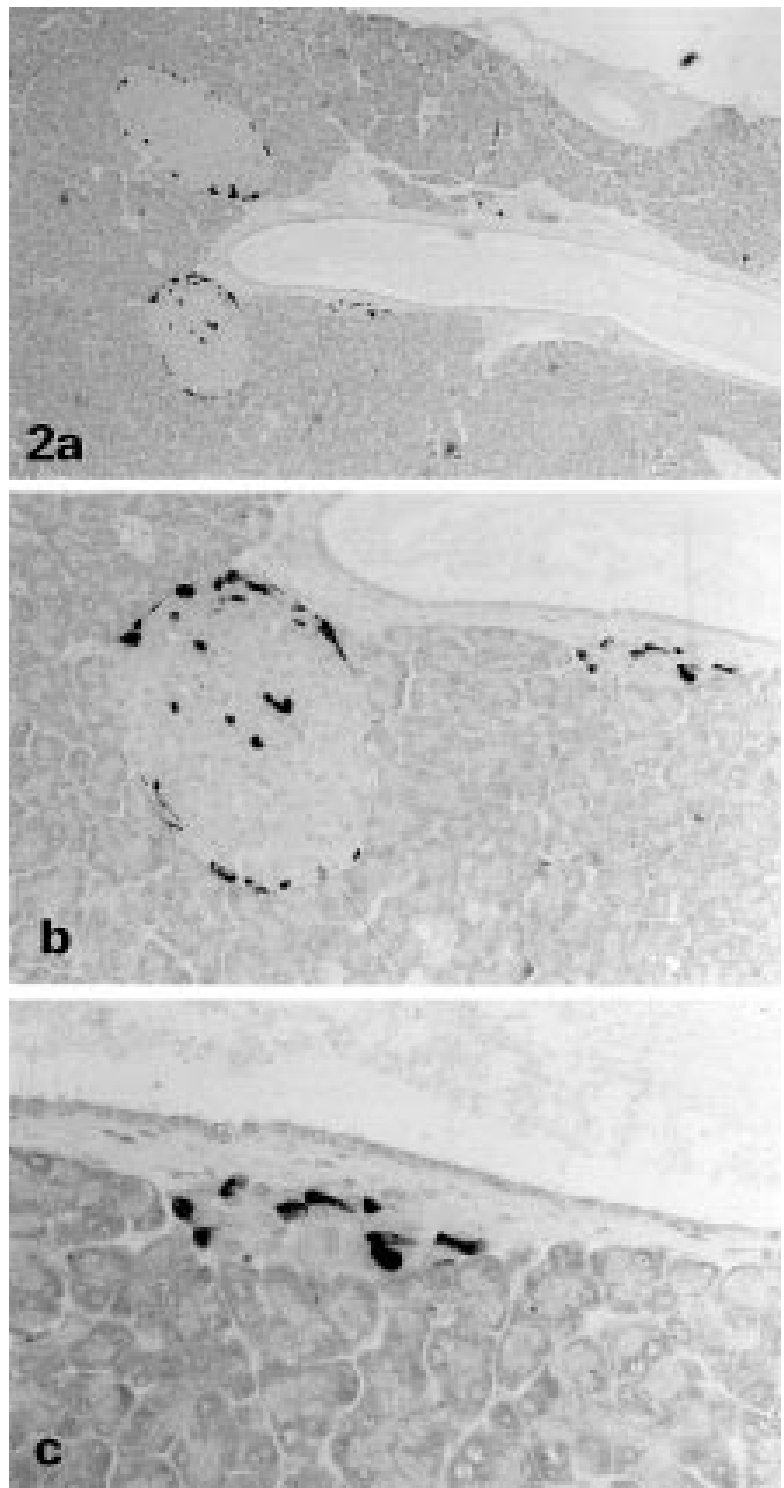

Fig. 2 - Glucagon-immunoreactive cells in the pancreas of the SKH-1 hairless mouse. These immunoreactive cells are found in the mantle and peripheral regions of pancreatic islets (a) and are also located in the islet-like cell masses situated in the subepithelial connective tissues of the pancreatic duct intermingled with other immunoreactive cells $(\mathrm{a} \sim \mathrm{c})$. In addition, some cells are demonstrated in the central region of pancreatic islets $(\mathrm{a}, \mathrm{b}) . \mathbf{a}: \times 48, \mathbf{b}: \times 120, \mathbf{c}: \times 240$, PAP method. 

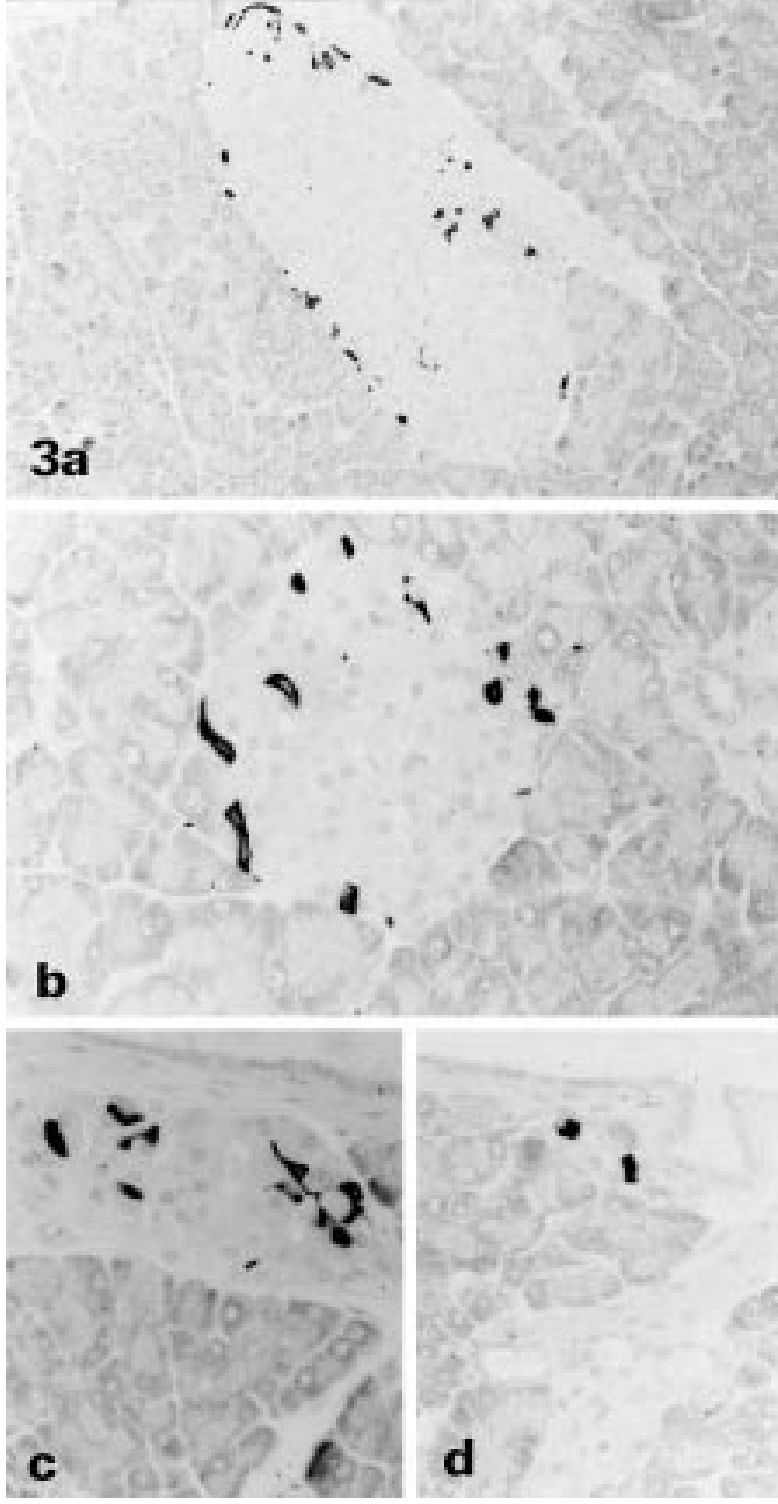

Fig. 3 - Somatostatin-immunoreactive cells in the pancreas of SKH-1 hairless mice. These cells are located in the similar regions to glucagon-immunoreactive cells in the pancreatic islets, exocrine and pancreatic duct portions $(\mathrm{a} \sim \mathrm{d})$ except for central regions of pancreatic islets. a: $\times 120, b \sim d: \times 240$, PAP method.

\section{In the exocrine portion}

Insulin- (Fig. 1c), glucagon-, somatostatin- and PP- (Fig. 4d) immunoreactive cells were demonstrated in this portion with $0.90 \pm 0.74,0.80 \pm$ $0.79,4.90 \pm 3.54$ and $2.70 \pm 1.34 / 100$ cells frequencies, respectively. They were randomly scattered between pancreatic acinar cells and interlobular connective tissues.
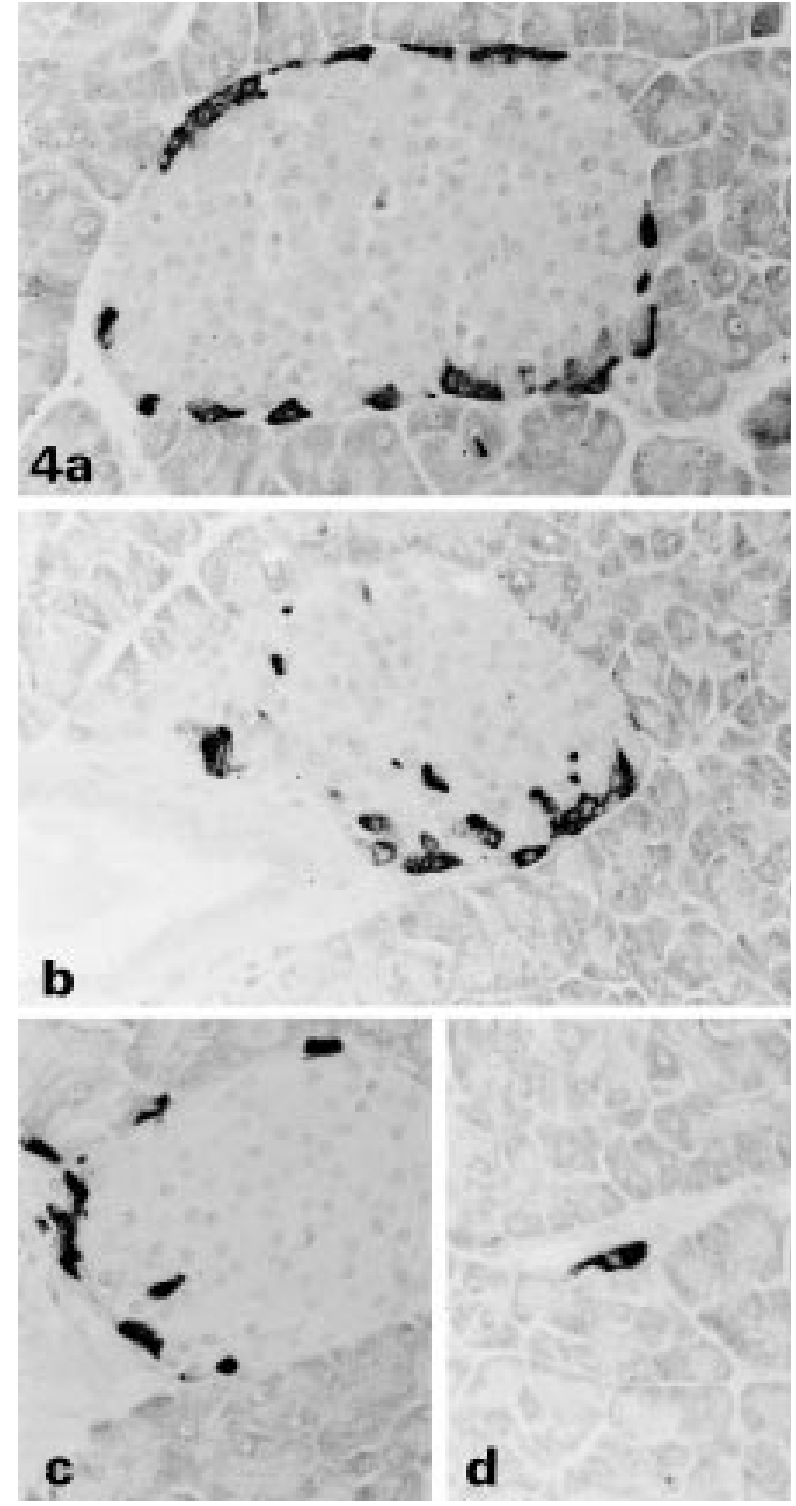

Fig. 4 - PP-immunoreactive cells in the pancreas of SKH-1 hairless mice.; Most of PP-immunoreactive cells are located in the outermost peripheral regions of pancreatic islets $(\mathrm{a}$

c) and exocrine portions (d). a $\sim \mathbf{d}: \times 240$, PAP method.

\section{In the pancreatic duct portion}

Insulin- (Fig. 1a, b), glucagon- (Fig. 2a-c) and somatostatin- (Fig. 3c, d) immunoreactive cells were situated in the subepithelial connective tissues with $30.30 \pm 14.67,2.70 \pm 3.13$ and $5.90 \pm$ $4.23 / 100$ cells frequencies, respectively. They formed islet-like cell masses but were randomly distributed in that portion, which differed from those of the pancreatic islets. 


\section{DISCUSSION}

Insulin is synthesized in the B cells of the pancreatic islets and regulates the serum glucose levels (Hsu and Crump, 1989). In mammals, the regional distribution and relative frequency of insulin-immunoreactive cells in the pancreas were reported in the wood mouse (Yukawa et al., 1999), hamster (Camihort et al., 2000), C57BL/6 mouse (Gomez-Dumm et al., 1995), voles (Sasaki et al., 1991), three-toed sloth (Bradypus variegates) (da Mota et al., 1992), Australian brush-tailed possum (Leigh and Edwin, 1992), opossum (Krause et al., 1989) and laboratory animals (Wieczorek et al., 1998). From these previous reports, it is well recognized that insulin-immunoreactive cells are situated in the central regions of pancreatic islets and other cells, such as glucagon-, somatostatin- and PP-immunoreactive cells, surround them. They were also demonstrated associated with acinar cells and pancreatic duct. However, unlike other researchers, Reddy et al. (1986) reported that these-immunoreactive cells were observed in most islets where they occurred as groups of cells peripherally and within the pancreatic islets of several marsupial species. In the present study, most of insulin-immunoreactive cells were restricted to the central regions of islets similar to those of previous rodents (Sasaki et al., 1991; Warbritton et al., 1994; Gomez-Dumm et al., 1995; Wieczorek et al., 1998; Yukawa et al., 1999; Camihort et al., 2000). Different from other rodents, where these cells were found in the lining epithelium of the pancreatic duct, insulin-immunoreactive cells were situated in the islet-like cell masses located in the subepithelial connective tissues of the pancreatic duct of the SKH-1 hairless mouse. This is considered to be a distributional pattern peculiar to the SKH-1 mouse .

Glucagon is synthesized in the A cells of the pancreas and regulates glucose levels in blood (Hsu and Crump, 1989). Morphologically similar cells are also observed in the digestive tract of the dog. In the present study, glucagon-immunoreactive cells were found in the mantle and peripheral regions of pancreatic islets. Although glucagonimmunoreactive cells were located in the mantle and peripheral regions of mammalian pancreatic islets, exocrine portions and pancreatic duct (Krause et al., 1989; Sasaki et al., 1991; da Mota et al., 1992; Leigh and Edwin, 1992; Warbritton et al., 1994; Gomez-Dumm et al., 1995; Wieczorek et al., 1998; Yukawa et al., 1999; Camihort et al., 2000), species-dependent variations were also reported. In the equine pancreas, A-cells demonstrated by anti-glucagon were found in the center of pancreatic islets where in most vertebrates insulin-immunoreactive cells were numerously found (Helmstaedter et al., 1976). In addition, it was also reported that under specific disease conditions, such as the obese (diabetic condition) mouse, glucagon-immunoreactive cells were intermingled with insulin-immunoreactive cells in the central regions of pancreatic islets; in contrast, normal non-obese littermates showed a peripheral localization of these immunoreactive cells (Starich et al., 1991). Although most of the glucagonimmunoreactive cells were situated in the mantle and peripheral regions of the pancreatic islets of the SKH-1 hairless mouse, cells with $4.00 \pm$ 2.83/100 cells frequency were also demonstrated in the central regions where numerous insulinimmunoreactive cells were located, and these results were different from those of other mammals. In addition, they were also situated in the islet-like cell masses located in the subepithelial connective tissues of the pancreatic ducts. These distributional patterns are considered to be peculiar patterns of the SKH-1 hairless mouse.

Somatostatin, which consists of 14 amino acids, was isolated from hypothalamus of sheep for the first time. It could be divided into a straight form and a cyclic form (Brazeau et al., 1973). This substance inhibited the secretion of the gastrin, cholecystokinin, secretin, glucagon, insulin, motilin and gastric acid (Kitamura et al., 1984) and the absorption of amino acids, glucose and fatty acids in the gastrointestinal tract (Brazeau et al., 1973). As far as is known, somatostatin-immunoreactive cells are located in the peripheral regions of mammalian pancreatic islets and exocrine portions (Krause et al., 1989; Sasaki et al., 1991; da Mota et al., 1992; Leigh and Edwin, 1992; Warbritton et al., 1994; Gomez-Dumm et al., 1995; Wiezorek et al., 1998; Yukawa et al., 1999; Camihort et al., 2000). Well corresponding to these previous studies, most of somatostatin cells were found in the mantle zones, where they were intermingled with glucagon- and PP-immunoreactive cells, and they occupied the outermost regions of pancreatic 
islets. Different from those of other reports, somatostatin-immunoreactive cells were situated in the islet-like cell masses located in the subepithelial connective tissues of the pancreatic ducts. This is again a peculiar distributional pattern for the SKH-1 mice.

$\mathrm{PP}$ is a peptide hormone containing 36 amino acids, which is synthesized by $\mathrm{F}$ cells in the pancreatic islets (Hsu and Crump, 1989). The specific function of this peptide is not clear; , however, inhibition of food intake has been postulated as a possible function of this peptide (Hsu and Crump, 1989). And Polak et al. (1976) reported that they promoted the secretion of gastric acid and stimulated the glycolysis of liver in avian species. It has been revealed that PP-immunoreactive cells were conspicuously distributed in the peripheral regions of pancreatic islets and exocrine portions in mammalian species, if they occurred (Krause et al., 1989; Sasaki et al., 1991; Leigh and Edwin, 1992; Warbritton et al., 1994; Gomez-Dumm et al., 1995; Wiezorek et al., 1998; Yukawa et al., 1999; Camihort et al., 2000). In addition, colocalization with serotonin in the pancreatic islets of the opossum (Krause et al., 1989) and cattle (Nakajima et al., 1988) was also demonstrated. In any event, da Mota et al. (1992) reported that PPimmunoreactive cells were not found in the pancreas of the three-toed sloth. In the present study, well corresponding to previous studies (Krause et al., 1989; Sasaki et al., 1991; Leigh and Edwin, 1992; Warbritton et al., 1994; Gomez-Dumm et al., 1995; Wiezorek et al., 1998; Yukawa et al., 1999; Camihort et al., 2000), PP-immunoreactive cells were detected in the outermost regions of pancreatic islets, although cells with $2.60 \pm 1.51 / 100$ cells frequency were intermingled with other immunoreactive cells in the mantle zone where glucagon-immunoreactive cells were most predominant.

In conclusion, some peculiar distributional patterns of pancreatic endocrine cells, especially, glucagon-immunoreactive cells, were demonstrated. In addition, unique distributional patterns in the pancreatic duct of the SKH-1 hairless mouse were also demonstrated.

\section{REFERENCES}

Alli-Rachedi A., Varndell I. M., Adrian T. E., Gapp D.A., Van Noorden S., Bloom S.R., and Polak J.M.: Peptide YY (PYY) immunoreactivity is co-stored with glucagon-related immunore- actants in endocrine cells of the gut and pancreas. Histochemistry $80,487-491,1984$.

Brazeau P., Vale W., Burgurs R., Ling N., Butcher M., Rivier J., and Guillermin R.: Hypothalamic polypeptide that inhibits the secretion of immunoreactive pituitary growth hormone. Science 179, 77-79, 1973

Cadi R., Beani J. C., Jacrot M., Pinel N., and Amblard P.: UVinduced squamous cell carcinomas in the hairless mouse. Morphological characteristics and transplantation in the syngenic and nude mouse. Acta Derm. Venereol. 71, 32-36, 1991.

Camihort G., Del Zotto H., Gomez-Dumm C.L., and Gagliardino J.J.: Quantitative ultrastructural changes induced by sucrose administration in the pancreatic B cells of normal hamsters. Biocell. 24, 31-37, 2000.

da Mota D.L., Yamada J., Gerge L.L., and Pinheiro P.B.: An immunohistochemical study on the pancreatic endocrine cells of the three-toed sloth, Bradypus variegatus. Arch. Histol. Cytol. 55, 203-209, 1992.

D'Este L., Buffa R., Pelagi M., Siccardi A.G., and Renda T.: Immunohistochemical localization of chromogranin $\mathrm{A}$ and $\mathrm{B}$ in the endocrine cells of the alimentary tract of the green frog, Rana esculanta. Cell Tissue Res. 277, 341-349, 1994.

Fu Q., Honda M., Ohgawara H., Igarashi N., Toyada C., Omori Y., and Kobayashi M.: Morphological analysis of pancreatic endocrine cells in newborn animals delivered by experimental diabetic rats. Diabetes Res., Clin. Pract. 31, 57-62, 1996.

Glaso M., and Wetteland P.: Morphometric evaluation of dark and clear epidermal basal cells during early 2-stage chemical skin carcinogenesis in the hairless mouse using two different fixation methods. APMIS 98, 695-712, 1990.

Gomez-Dumm C.L., Console G.M., Lunna G.C., Dardenne M., and Goya R.G.: Quantitative immunohistochemical changes in the endocrine pancreas of nonobese diabetic (NOD) mice. Pancreas 11, 396-401, 1995.

Harnby D., Gowland G., Holland K.T., and Kearney J.N.: The cutaneous microbiology of haired and hairless mice. Appl. Bacteriol. 69, 686-691, 1990.

Helmstaedter V., Feurle G.E., and Forssmann W.G.: Insulin-, glucagon- and somatostatin-immunoreactive cells in the equine pancreas. Cell Tissue Res. 172, 447-454, 1976.

Hsu W.H., and Crump M.H.: The endocrine pancreas. In Veterinary endocrinology and reproduction. (Eds. McDonald, L.E. and Pineda, M.H.), Lea \& Febiger, Philadelphia, pp. 186-201, 1989.

Ito H., Hashimoto Y., Kitagawa H., Kon Y., and Kudo N.: Distribution of chromogranin containing cells in the porcine gastroenteropancreatic endocrine system. Jpn. J. Vet. Sci. 50, 395-404, 1987.

Jansson L., and Sandler S.: The influence of cyclosporin A on the vascular permeability of the pancreatic islets and on diabetes induced by multiple low dose of streptozotocin in the mouse. Virchows Archiv. A Pathol. Anat. Histopathol. 412, 225-230, 1988. 
Kitamura N., Yamada J., Calingasan N.Y., and Yamashita, T.: Immunocytochemical distribution of endocrine cells in the gastrointestinal tract of the horse. Equine Vet. J. 16, 103-107, 1984.

Kobayashi K., and Ali S.S.: Cell types of the endocrine pancreas in the shark, Scylliorhinus stellaris as revealed by correlative light and electron microscopy. Cell Tissue Res. 215, 475-490, 1981

Kommuru T.R., Khan M.A., and Reddy I.K.: Effect of chiral enhancers on the permeability of optically active and racemic metroprolol across hairless mouse skin. Chirality 11, 536-540, 1999.

Krause W.J., Cutts J.H.3rd, Cutts J.H., and Yamada J.: Immunohistochemical study of the developing endocrine pancreas of the opossum (Didelphis virginiana). Acta. Anat. (Basel) 135, 84-96, 1989.

Leigh C.M., and Edwin N.A.: Light-microscopic immunocytochemical study of the endocrine pancreas in the Australian brush-tailed possum (Trichosurus vulpecula). Eur. J. Histochem. 36, 237-241, 1992.

Nakajima S., Kitamura N., Yamada J., Yamashita T., and Watanabe T.: Immunohistochemical study on the endocrine pancreas of cattle with special reference to coexistence of serotonin and glucagon or bovine pancreatic polypeptide. Acta Anat. (Basel) 131, 235-240, 1988

Orci L.: Macro- and micro-domains in the endocrine pancreas. Diabetes. 31, 538-564, 1982.

Packchanian A, Emery R, MacDonald E.M., and Rigdon R.H.: Experimental leprosy with Mycobacterium lapraemurium in hairless mice (Mus musculus). Trans. R Soc. Trop. Med. Hyg. 76, 183-186, 1982.

Polak J.M., Adrian T.E., Bryant M.G., Bloom S.R., Heitz P.H., and Pearse A.G.E.: Pancreatic polypeptide in the insulomas, gastrinomas and glucagonomas. Lancet 1, 328-330, 1976.

Reddy S., Bibby N.J., Fisher S.L., and Elliott R.B.: Immunolocalization of insulin, glucagon, pancreatic polypeptide and somatostatin in the pancreatic islets of the possum, Trichosurus vulpecula. Gen. Comp. Endocrinol. 64, 157-162, 1986.

Rindi G., Buffa R., Sessa F, Tortora O., and Solcia E.: Chromogranin $\mathrm{A}, \mathrm{B}$ and $\mathrm{C}$ immunoreactivities of mammalian emdocrine cells: Distribution from costored hormones/prohormones and relationship with argyrophil component of secretory granules. Histochemistry 85, 19-28, 1986.

Sasaki M., Arai T., Usui T., and Oki Y.: Immunohistochemical, ultrastructural, and hormonal studies on the endocrine pancreas of voles (Microtus arvalis) with monosodium aspartate-induced diabetes. Vet. Pathol. 28, 497-505, 1991.

Starich G.H., Zafirova M., Jabelenska R., Petkov P., and Lardinois C.K.: A morphological and immunohistochemical investigation of endocrine pancreas from obese ob+/ob+ mice. Acta Histochem. 90, 93-101, 1991.

Sternberger L.A.: The unlabeled antibody peroxidase-antiperoxidase (PAP) method. In Immunocytochemistry (Ed. Sternberger, L.A.), John Wiley \& Sons, New York, pp. 104-169, 1979.
Sternberger L.A., Hardy P.H., Cuculis J.J., and Meyer H.G.: The unlabeled antibody enzyme method of immunocytochemistry: Preparation and properties of soluble antigen-antibody complex (Horseradish peroxidase-antihorseradish peroxidase) and use in identification of spirochetes. J. Histochem. Cytochem. 18, 315-333, 1970.

Warbritton A., Gill A.M., Yen T.T., Bucci T., and Wolff G.L.: Pancreatic islet cells in preobese yellow Avy/- mice: relation to adult hyperinsulinemia and obesity. Proc. Soc. Exp. Biol. Med. 206, 145-151, 1994

Wieczorek G., Pospischil A., and Perentes E.A.: Comparative immunohistochemical study of pancreatic islets in laboratory animals (rats, dogs, minipigs, nonhuman primates). Exp. Toxicol. Pathol. 50, 151-172, 1998.

Yamada J., Campos V.J.M., Kitamura N., Pacheco A.C., Yamashita T., and Yanaihara N.: An immunohistochemical study of endocrine cells in the pancreas of Caiman latirostris (Alligatorinae), with special reference to pancreatic motilin cells. Biomed. Res. 7, 199-208, 1986

Yukawa M., Takeuchi T., Watanabe T., and Kitamura S.: Proportions of various endocrine cells in the pancreatic islets of wood mice (Apodemus speciosus). Anat. Histol. Embryol. 28 , 13-16, 1999. 